\title{
REGIONAL LABOUR MARKET AND DEPOPULATION - AN ASSESSMENT OF THE SITUATION IN THE PODKARPACKIE VOIVODESHIP
}

\begin{abstract}
Currently, the aging population is an important phenomenon facing Europe. This study focuses on demographic changes and their importance for the labour market that are becoming a more noticeable problem in Poland. The conditions of depopulation have a significant impact on the size of labour demand and supply.

The article characterizes selected factors that determine the phenomenon of depopulation and its impact on labour market changes. The main aim of this study is to present the situation on the Polish modern labour market (using the example of Podkarpackie Voivodeship) within the context of assessing the dynamics of changes in selected parameters in relation to the process of current and future depopulation. The researchers used the desk research method and descriptive statistical analysis to analyze the data. In addition, there was an analysis of the following demographic measures: age dependency ratio, total fertility rate (TFR), population growth, and net migration. Additionally, the authors describe the statistical measures related to the labour market such as e.g. registered unemployment rate. The time range includes the years 2012-2018 and forecasts from current time until 2050.
\end{abstract}

Keywords: regional labour market, depopulation, migration, ageing society.

\section{INTRODUCTION}

As a result of globalization, sharing open inter-state borders in European Union and intensification of human capital mobility, Polish enterprises have clearly felt the economic pressure related to, among others, increased competitiveness of economies and economic entities (Drzeżdżon, 2011), which led to numerous consequences for the functioning of the labour market.

On one hand, transformation of the Polish labour market linked to the changes in forms of employment ${ }^{3}$, expansion of the potential area of business activity, flexibility growth of the company's organizational structure and higher number of potential players on the

\footnotetext{
${ }^{1}$ Anna Barwińska-Małajowicz, DSc PhD, Associate Prof. UR, University of Rzeszow, Institute of Economics and Finance, ul. Mieczysławy Ćwiklińskiej 2, 35-601 Rzeszow; e-mail: abarmal@gmail.com (corresponding author). ORCID ID: 0000-0002-0228-1761.

2 Kamila Tęcza, MSc, University of Rzeszow, Institute of Economics and Finance, ul. Mieczysławy Ćwiklińskiej 2, 35-601 Rzeszow; e-mail: tecza.kamila@wp.pl. ORCID ID: 0000-0002-1602-0204.

${ }^{3}$ As a result of enterprises development, so-called outsourcing starts to play a greater role that improves the company's operations by delegating responsibilities outside the company; in addition, new forms of employment began to be used, e.g. job sharing, home office etc.
} 
market, resulted in increased demand for work. What is more, the recruitment of highly qualified staff has also become a priority for employers. On the other hand, the same factors considered from the employee's perspective, contributed to the higher number of job offers, wage competitiveness and expanding the possibilities of free choice of working conditions ${ }^{4}$, which successively changed the profile of the Polish labour market from the so-called "employer's market" to "employee market". Through generational changes, transport infrastructure development and socio-spatial which are the results of globalization on the labour market, the phenomenon of atrophy of employee attachment to both the place of living (Trąbka, 2018) and to the work itself began to be noticed. In the 21 st century attention was paid to the process of transition from a "safe" employment system preferred by employers (characterized for example by permanent employment, less frequent job change etc.) to more risky, decentralized (Beck, 2004).

Along with the development of the labour market, another, originally unnoticed and underestimated problem was growing in Poland: demographic changes which lead to the phenomenon of depopulation. In recent years, it is the determinants of elaborated phenomenon that are beginning to increasingly affect the shaping of the supply and demand side of the labour market (Brzychcy, 2011). In the face of depopulation, Polish entrepreneurs began an intensified struggle for an employee, not only national but also the foreign one, changing simultaneously the scale and directions of economic migration.

The effects of depopulation are already noticeable in the current labour market. However, according to the forecasts of the Central Statistical Office (CSO), a population regression, not only related to the decrease the number of Polish citizens, but also to the structural changes in Polish society, will accelerate over the next several years. The consequences will be noticeable for example on regional labour markets, especially in regions where the unemployment rate and the degree of mismatch are already high, creating inefficient surpluses and deficits in professions (Podkarpackie Voivodeship is one of those areas).

The main aim of this study is to present the situation on Polish, current labour market (by the example of Podkarpackie Voivodeship). This paper presents the analysis conducted in the context of assessing the dynamics of changes of selected parameters in relation to the process of current and future depopulation. Methods used in this article, in relation to the existing data related to the undertaken issue, are the desk research method and descriptive statistical analysis. The following demographic and labour market measures were analyzed e.g registered unemployment rate, age dependency ratio, total fertility rate (TFR), population growth and net migration. The time range includes the years 2012-2018 and the forecast reaching the year 2050. In 2018, according to the statistical data of CSO, Podkarpackie Voivodeship was one of two Voivodeships ${ }^{5}$ with the highest equity of people in working age among all inhabitants of the region $(62.0 \%)$. Labour market participation rate reached the value of 55.4\% (4Q2018) which was the 7th position compared to the other fifteen Polish Voivodships. Despite the good economic situation that affects the labour market improvement, Podkarpackie Voivodeship has the highest unemployment rates in Poland and a surplus of demand over labour supply, the consequences of which were visible in the number of vacant jobs at the end of 2018. In this case, it is reasonable to analyze the potential threats to the mentioned labour market with regard to the depopulation forecast.

\footnotetext{
${ }^{4}$ And also an increased mobility and the possibility of remote working.

5 The next one was the Opolskie Voivodeship.
} 
Statistical data aggregated as part of this publication come from the CSO databases. Graphic interpretations of selected indicators were also presented. The first part of this study contains a theoretical outline, showing the phenomenon of depopulation and its impact on the current labour market. Further fragment presents the dynamics of changes in selected indicators that shows the current situation on the Podkarpackie labour market and also includes an attempt that has been made to analyze forecasts regarding the phenomenon of depopulation as a potential threat to the functioning of the regional labour market. Whole article ends up with a synthetic summary of the taken considerations.

\section{DEPOPULATION AS ONE OF THE DETERMINANTS THAT SHAPES MODERN LABOUR MARKET}

Depopulation, as a phenomenon of population decline, has accompanied our civilization since the dawn of time. The root of this demographic process were mostly violent and dynamic factors, such as epidemics, wars, natural disasters and mass migrations. The scale of depopulation and its implications in the form of demographic structure changes are examined by demographers essentially in terms of sociological and geographical background. As a result of multi-dimensional area of mentioned phenomenon, differential causes, uncontrolled direction of changes and unclear measurability, the economic aspect, including the impact of depopulation on shaping of labour markets, is often underestimated or not fully appreciated. Nevertheless, depopulation is sometimes mentioned in the literature as one of the main threats to proper functioning of regional, national and global markets (including labour markets), as well as the cause of market imbalance (Guzikowski, 2016). Its economic aspect is extremely important, because taking into consideration depopulation underlying the basis for creating new strategies for authorities (adapted to current realities) that may have support socio-economic development ${ }^{6}$.

The following depopulation (in contrary to previous years) depends on diverse and dynamically changing factors of a dual nature: sociological and economical. Its causes have more unitary nature (which appeared only in scale effect) and they are bound to e.g. individual decisions and motives such as comfort of life, increase of people's awareness, change of priorities etc. In the wake of lack of stability and control of its individual components, current depopulation is a highly dangerous phenomenon. What is more, its evolution and intensification in Europe enforce the reform of the population demographic development approach, which resulted in so-called New demographics of Europe concept (Kotowska, Jóźwiak, 2012).

As factors that shape the modern type of depopulation, related literature includes the following phenomena:

- increased life expectancy;

- low total fertility rates (without the generational replacement quarantee);

- populations age structure changes (ageing society);

- intensive migration (negative net migration) (Dybowska, Widera, 2015).

A further important point to note is that the above factors also determine the labour supply volume and structure and also have a direct impact on the scale and structure of demand on labour market e.g. by amending changes in labour costs and productivity

\footnotetext{
6 The current dynamics of demographic changes will not only result in subsequent changes in the
} labour market policy but will also affect the form of the national migration policy. 
(Dylkiewicz, 2013). In addition, according to the New demographic concept, the effect of a chronic decline in female fertility, prolonged life expectancy and increased migration will be permanent changes in all market structures, which in the long-term forecast will translate into the development of European economies slowdown (Kotowska, Jóźwiak, 2012).

Depopulation issue is also a concern of one of the sociological theory such as Demographic transition theory (Warren Thompson, 1929). In compliance with its theses, the demography of a country depends on the degree of development of its economy. First two transition phases (phase I and phase II) relate to pre-industrial and industrial society, are characterized by instability and high birth rates ${ }^{7}$. The actual demographic transition begins in phase III, when the country turns into developing country (increase in life expectancy and participation of people in retirement age in entire population, population growth decrease $)^{8}$. The last, 4th phase apply developed countries, including European countries such as Poland (Grzywna, 2014) and in these economies depopulation occurs in the developmental meaning (increased professional activity of women, family model $2+1$, career- orientated persons, stabilization of birth rate on low level). Taking into account all these considerations, depopulation may be regarded as antagonism - being both a determinant of development and a factor inhibiting it.

Dynamic changes that occurs in population structures has created some framework for the so-called double aging concept (Adamczyk, 2017), more frequently, discussed in the literature on the subject. Double aging concept focus on the interplay between the dynamics of increase in number of people in particular age category. The post-working age population can be divided into persons aged 65-74, 75-84 and the oldest, i.e. over 85 years of age. Double aging phenomenon may be discussed only when an intensive increase in the oldest population (85+) is noticeable with a less dynamic change in the size of the population aged 65-74. It's also the next threat to well-functioning labour markets, which is related to the intensive increase in the number of the oldest population, unable to work and the relatively low increase in the number of people potentially able to be reactivate (65-74 years of age). This situation may have the additional effect of a change in the demand for employees in the area of medical care (Adamczyk, 2017).

Population shrinking affects both the change in the model of society, and has its consequences for the labour market and the behavior of its players. That is why, this phenomenon should be considered not only in the sociological, but also in economic terms. Furthermore, depopulation results in deepening supply and demand imbalance (lack of workforce, mismatch between qualifications and job offers), which slow down the development and competitiveness of a country. The depopulation effect may also have an impact on the inefficient use of existing human capital (too little activation of the elderly, waste of the potential of national capital).

\subsection{Demographic measures related to the phenomenon of depopulation in the labour market context}

The classic measure of demographic dependency which affects the labour market is the age dependency ratio related to the phenomenon of population ageing. According to the CSO definition this factor relates to the ratio of number of people in non-working age to the number of people in working age. The higher the indicator volume is, the lower supply of

\footnotetext{
${ }^{7}$ E.g. countries of the African continent are in mentioned phases nowadays.

${ }^{8}$ E.g. India, China.
} 
labour force in the labour market. Moreover, age dependency ratio growth is a barrier to countries operating a pension system based on people of working age - an obstacle to receiving health and retirement benefits (such as Poland).

Another measure used in the demographic change analysis is the total fertility rate (TFR). In order to achieve stable demographic development, and thus move towards balance in the labour market, the TFR should strive to 2.10 / 2.15 value (on average there are two children per one woman aged 15-49). Depending on the value of this indicator (Table 1), it can be concluded that the generation replacement is on high or low level.

Table 1 . Total fertility rate - generational replacement and consequences on the labour market

\begin{tabular}{|c|c|c|c|}
\hline $\begin{array}{l}\text { Total fertility rate } \\
\text { (TFR) }\end{array}$ & $\mathrm{TRF}<2.10$ & $2.1 / 2.15$ & $\mathrm{TRF}>2.15$ \\
\hline $\begin{array}{l}\text { Consequences for the } \\
\text { labour market }\end{array}$ & $\begin{array}{l}\text { no generational } \\
\text { replacement (low } \\
\text { fertility trap) } \\
\text { labour deficit; } \\
\text { imbalance in the } \\
\text { labour market; }\end{array}$ & $\begin{array}{l}\text { simple generational } \\
\text { replacement (desired } \\
\text { condition) } \\
\text { stability of the } \\
\text { population structure; } \\
\text { effective adjustment } \\
\text { of supply to demand } \\
\text { on the labour market }\end{array}$ & $\begin{array}{l}\text { overpopulation; } \\
\text { oversupply of labour; } \\
\text { high level of } \\
\text { unemployment; }\end{array}$ \\
\hline
\end{tabular}

Source: Own study based on (Szukalski, 2015).

The reasons for low fertility ratio can be found in the so-called low female fertility (caused by stress, increased professional activity etc.), as well as in the lack of families financial comfort (Kotowska, 2014) ${ }^{9}$. In this case, another cognitive dissonance is noticeable. The low level of TFR has a negative impact on the labour market, but it is the elements of this market (i.e. insecurity of employment, unsatisfactory pay etc.) that are inhibiting fertility.

The value of the next two factors that determines depopulation, i.e. negative population growth and scale of population migration, has already been noticed in scientific analyzes of Polish interwar period. These factors, closely related to each other, also play an important role in creating labour supply in a country (Jędruszczak, 1964). What is more, population changes are no longer included just as form of the value of the population growth generated by the inhabitants of the area or the demographic dependency ratio. The net migration and the dynamics of migration movements of the society has also become an integral factor that forms scale of depopulation. This is also extremely important due to the proven impact of migration on the development of processes taking place on the labour market (Jóźwiak, 2013).

Current migration processes has become a kind of axiom for the functioning of the labour market (Barwińska-Małajowicz, Tęcza, 2018). The globalization, development of transport, reduction of barriers related to crossing borders as well as the reduction of language barriers (universal access to education) have improved the mobility of the society.

\footnotetext{
${ }^{9}$ Over the past decade, the average age of women for their first child has also increased (according
} to Eurostat data for the European Union in 2013 it was about 29 years, and in 2018 - about 31 years). 
Migration began to be treated as a remedy for the proper functioning of labour markets in terms of deficits or oversupply (the lack of employment opportunities in one country is often a motivator for migration, and to supply another labour market with a deficit in a given profession). In short, according to the macroeconomic theory of migration create by A. Lewis, increasing labour mobility has both positive and negative implications for the national and regional labour markets (Table 2).

Table 2. The impact of migration on the labour market

\begin{tabular}{|l|c|c|}
\hline \multicolumn{3}{|c|}{ Migration and labour market } \\
\hline & Sending country (emigration) & Host country (immigration) \\
\hline negative implication & $\begin{array}{c}\text { loss of native human capital; } \\
\text { GDP decline } \\
\text { employee intolerance); }\end{array}$ & $\begin{array}{c}\text { increased labour supply (increased } \\
\text { competitiveness between } \\
\text { employees) }\end{array}$ \\
\hline positive implication & $\begin{array}{c}\text { unemployment decline; } \\
\text { increase wages to maintain } \\
\text { capital in the company's } \\
\text { structure; } \\
\text { migrants' income transfer; } \\
\text { increased qualifications of } \\
\text { returning employees. }\end{array}$ & $\begin{array}{c}\text { knowledge transfer; } \\
\text { filling gaps in shortage } \\
\text { occupations. }\end{array}$ \\
\hline
\end{tabular}

Source: Own study based on (Golinowska, 2011).

\section{LABOUR MARKET IN THE PODKARPACKIE VOIVODSHIP IN THE FACE OF DEPOPULATION - CURRENT SITUATION AND FORECAST}

The population of the Podkarpackie Voivodeship has not changed much since its creation $^{10}$. The lack of extreme changes, both in the number and structure of the population, effectively distanced the current analyzes of depopulation as a potential threat to the Podkarpackie economy. Thus, Podkarpackie labour market policy was focused mainly on tackling the high unemployment rate, which was one of the highest value in Poland in 2018 $-8.8 \%$ (Fig. 1).

The largest group among the unemployed citizens of Podkarpackie region were aged 25-34 $(30.2 \%)^{11}$, followed by those aged 35-44 (23.2\%). In addition, in 2018 there were on average 28 unemployed persons per job offer. Over 30,000 new jobs were created, and around 14,000 were lost.

Another paradox is related to the issue of the increase in the number of vacancies on the Podkarpackie labour market. Despite the high rate of economically active persons, as well as the above-mentioned high unemployment rate, at the end of the 4Q2018, there were about 4,000 vacancies (including 1,200 newly created jobs), which means that in comparison to the previous year, the number of vacancies increase on $15 \%$. The highest number of vacancies were registered for craft and related trades workers as well as plant and machine operators and assemblers (Fig. 2). One of the main factor which may determine this

\footnotetext{
${ }^{10} 1999$.

${ }^{11}$ The higher value of the indicator was noticed only for the Lubelskie Voivodeship $-31.1 \%$.
} 


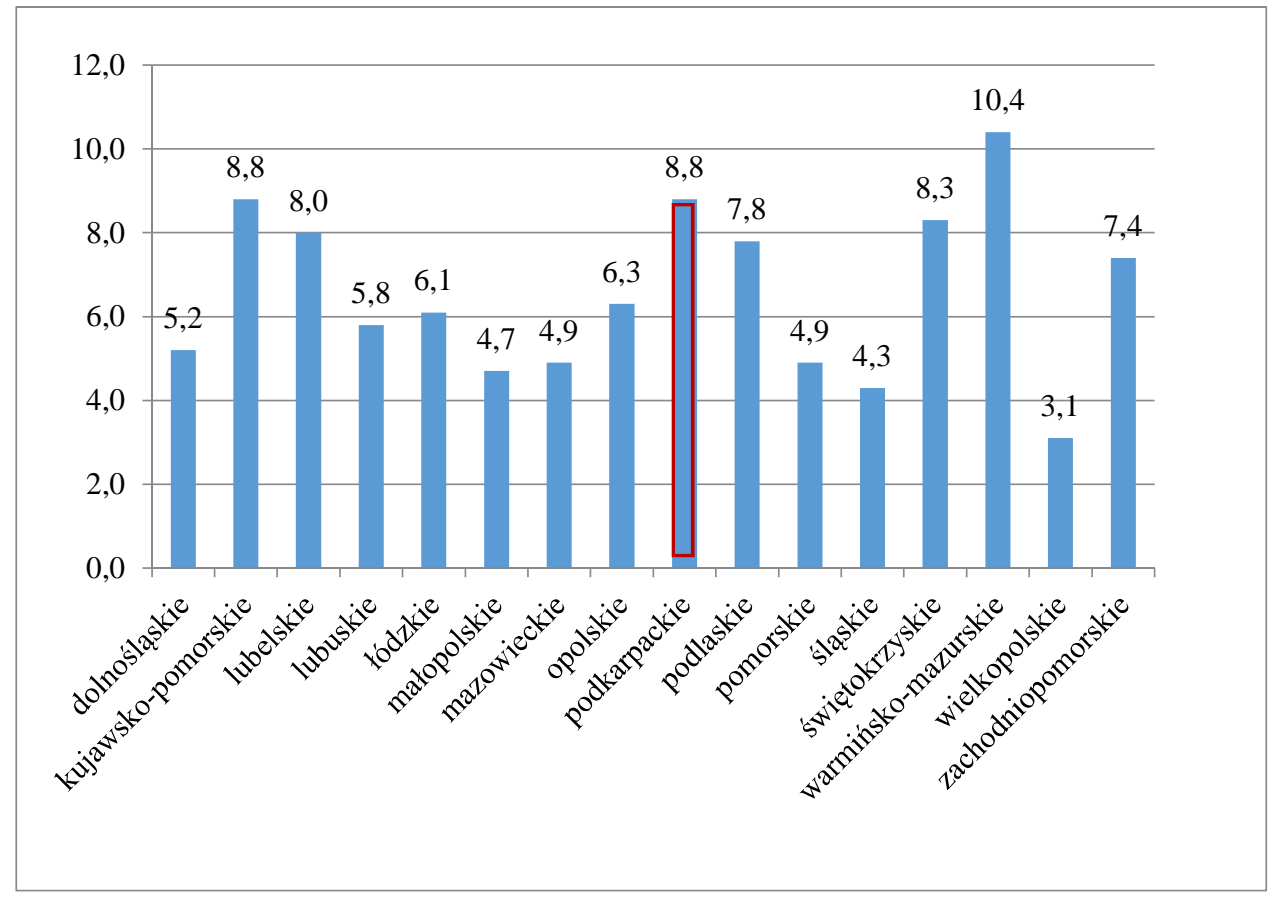

Fig. 1. Registered unemployment rate in Poland by Voivodships in the year 2018 [\%]

Source: Own study based on statistical data of Central Statistical Office.

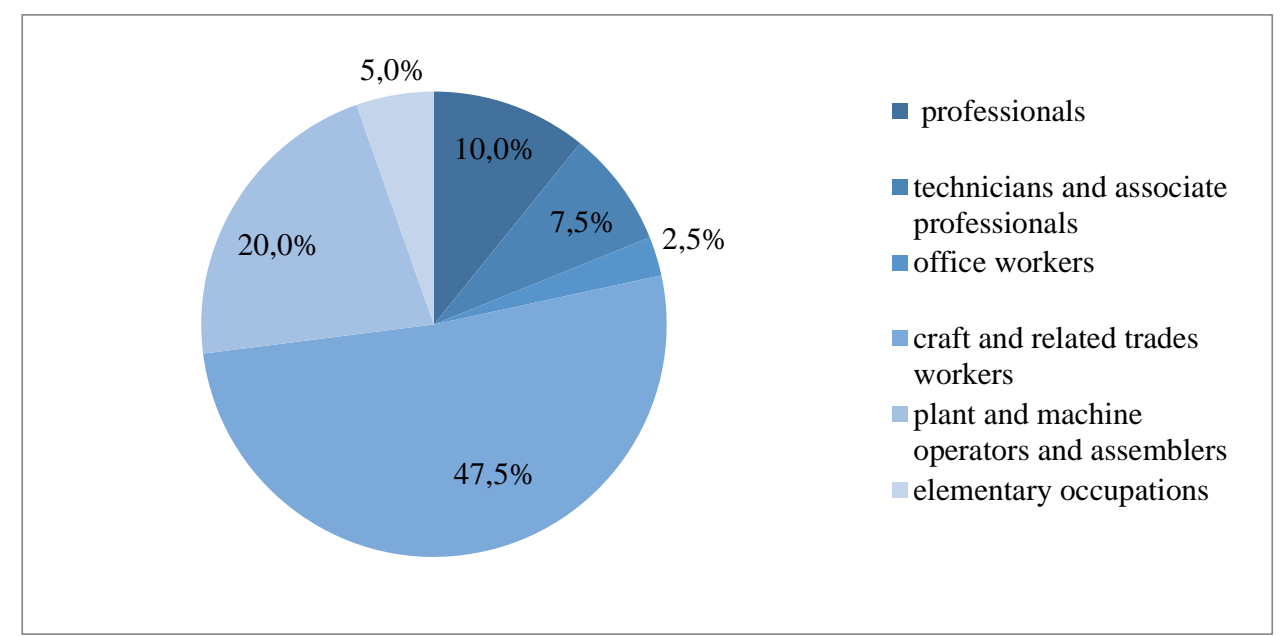

Fig. 2. Job vacancies by selected occupations at the end of the 4Q2018 - Podkarpackie Voivodeship

Source: Own study based on statistical data of Central Statistical Office. 
situation may be the lack of tailored to the needs between job offers and the qualifications of potential employees. Most of the above professions are professions requiring special qualifications related to the specialist courses or vocational schools (Education development program in the Podkarpackie Voivodeship until 2020 ..., 2017).

The analysis of available data indicates that the situation on the Podkarpackie labour market may deteriorate as a result of adverse changes (e.g. the beginning of the depopulation process) observed in recent years. Moreover, some of reaserchers expects that this tendency may be accelerated (Koprowicz, 2017). CSO forecast ${ }^{12}$ confirm that in the following years the population of the Podkarpackie Voivodeship will decrease - a decrease of $0.7 \%$ in 2020 compared to 2018 (Fig. 3).

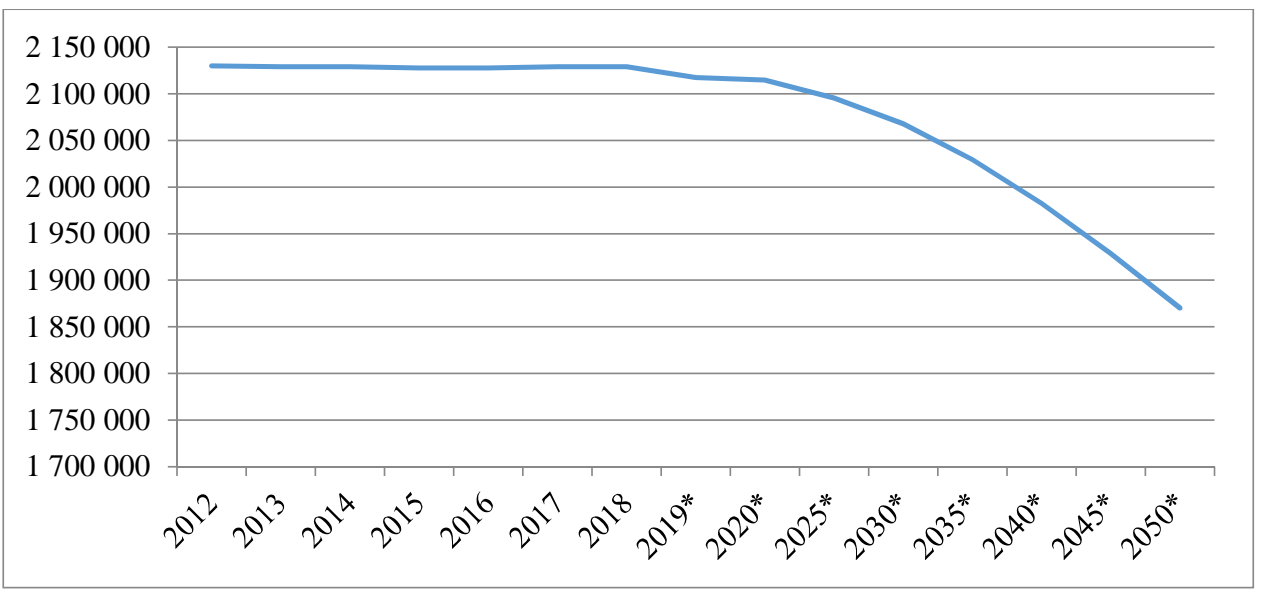

Fig. 3. Population of the Podkarpackie Voivodeship in 2012-2018 with a forecast* (number of people)

Source: Own study based on statistical data of Central Statistical Office

The first signs of a decreasing population in the Podkarpackie Voivodeship were noticed in 2013 , however, the dynamics of these changes $(0.03 \%$ year-over-year) did not liable to endanger the functioning of the labour market. In 2018, Podkarpackie region was inhabited by $2,129.015$ people. CSO forecast show that by the end of 2050 this area will be inhabited by less than 2 million people ( $1,870.343$ people - a $12.1 \%$ of decrease compared to 2018 ), which raises legitimate concern regarding the functioning of the labour market ${ }^{13}$. In addition, the analysis of data by poviats shows that only in one of them - Rzeszów, the population will increase slightly until 2050 . In the next 25 poviats (including cities with poviat status), an average decrease, compared to 2018 , is on approx. $15 \%$ level $^{14}$.

In order to undertake a meaningful assessment of the impact of population decline on the Podkarpackie labour market, a detailed breakdown of the Podkarpackie Voivodeship population has been done, including economic age groups (Fig. 4): pre-working age group

${ }^{12}$ Forecasts were prepared in 2014 for the years 2014-2050.

${ }^{13}$ CSO forecast were prepared in 2014. It should be noted that, according to the same forecast, by 2050 in Poland as a country over $11.6 \%$ of the population will be depleted.

14 CSO data. Forecast for 2050 
(less than 17 years old); working age group (aged 18-60/65); post-working age/retirement age group (60/65 years old and more). What is more, the authors specified the sphere of mobile working age (18-44 years old) and immobile working age (the age between 45 and $60 / 65)$.

$2018 \mathrm{r}$.

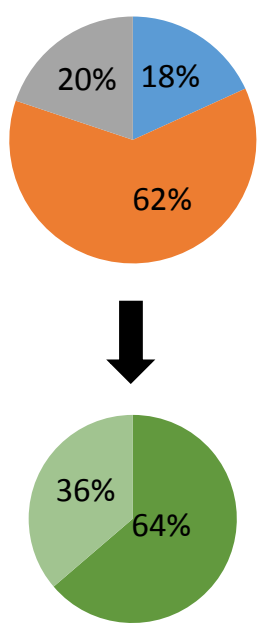

2050*

$14 \%$

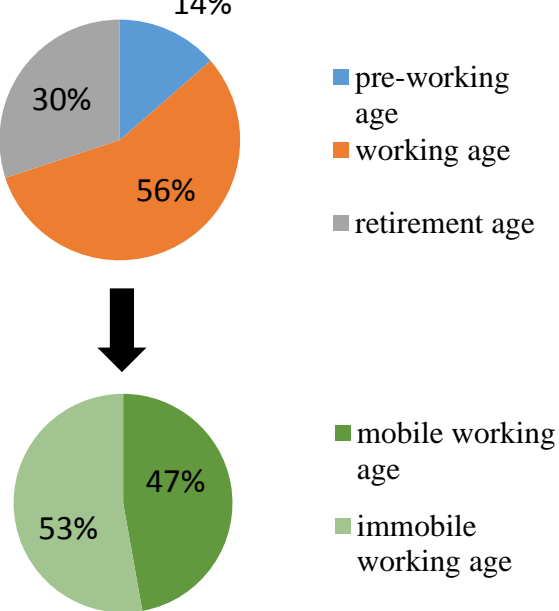

Fig. 4. Population of the Podkarpackie Voivodeship, including economic age groups in the year 2018 and the forecast*

Source: Own study based on statistical data of Central Statistical Office.

The analysis of data presented at Fig. 4 shows that the dominant group of working population in Podkarpackie Voivodeship is a working age group $(62.0 \%) .63 .7 \%$ of it is the mobile population in working age, which means that the majority of economically active citizens of Podkarpackie are able to change jobs or retraining. However, the slow aging process of the Podkarpackie Voivodeship population is being noticed. According to the CSO data, in the Podkarpackie Voivodeship (in all poviats and cities with poviat status), people in post-working age reached approx. 1/5 of all inhabitants of the each administrative units. In addition, forecast shows negative changes of the Voivodeships age structure.

By 2050, the number of people in working age will decrease by almost $20.1 \%{ }^{15}$, including the number of people of immobile working age, thus they will represent more than half of all working active people. The current "labour shortage" despite the desirable age of the citizens, leads to the conclusion that a decrease of this indicator (from $62.0 \%$ to $56.3 \%$ ) may aggravate the problem of finding a suitable employee, which in turn may imply a decrease in quality or an increase in services/product cost (salary as a motivating factor for a potential employee) as well as seeking labour resources abroad. Taking into consideration the fact that people of immobile working age do not express a desire to change jobs, this can significantly reduce the scale of emigration (internal and external), which will

\footnotetext{
${ }^{15}$ Year-over-year comparison. Base year: 2018.
} 
retain the resources of regional human capital. On the other hand, it is more difficult for these people to retrain, which may inhibit the development of the Podkarpackie labour market and the entire economy of Podkarpackie Voivodeship.

In 2018, the demographic dependency ratio for the Podkarpackie Voivodeship, calculated as the ratio of the number of people in non-working age to the number of people in working age, was on 61.4 level and was the second lowest value of the indicator throughout the country ${ }^{16}$. This mean that there were about 61 people in non-working age per 100 people of working age (about 2 people of working age per one elderly person). According to the forecast, by 2050 in the Podkarpackie Voivodship the number of people per one person of non-working age will be 1: 1 (Table 3). As it was mentioned in first part of this article such situation may results in increase development of medical care in Voivodeship. It is worth noting that in 2018 professions such as medical staff and carer of the elderly persons were already in shortage professions (Occupational Barometer..., 2018).

Table 3. Value of the demographic dependency ratio for the Podkarpackie Voivodeship in the year 2018 with the forecast*

\begin{tabular}{|c|c|c|c|c|c|c|}
\hline $\begin{array}{c}\text { Year of } \\
\text { the } \\
\text { forecast } \\
\text { pre- } \\
\text { working } \\
\text { of persons] }\end{array}$ & $\begin{array}{c}\text { working } \\
\text { age) } \\
\text { [numer of } \\
\text { persons] }\end{array}$ & $\begin{array}{c}\text { retirement } \\
\text { age [numer } \\
\text { of persons] }\end{array}$ & $\begin{array}{c}\text { non- } \\
\text { productive } \\
\text { age- the } \\
\text { sum of pre- } \\
\text { working and } \\
\text { retirement } \\
\text { age [numer } \\
\text { of persons] }\end{array}$ & $\begin{array}{c}\text { age } \\
\text { dependency } \\
\text { ratio } \\
\text { [people in } \\
\text { non- } \\
\text { productive } \\
\text { age per 100 } \\
\text { people of } \\
\text { working age] }\end{array}$ & $\begin{array}{c}\text { dependency } \\
\text { ration per 1 } \\
\text { person in } \\
\text { non- } \\
\text { productive } \\
\text { age }\end{array}$ \\
\hline 2018 & 387423 & 1319331 & 422261 & 809684 & $\mathbf{6 1 . 4}$ & $\mathbf{1 . 6}$ \\
\hline $2019 *$ & 376570 & 1354578 & 386399 & 762969 & $\mathbf{5 6 . 3}$ & $\mathbf{1 . 8}$ \\
\hline $2020^{*}$ & 373559 & 1350308 & 390728 & 764287 & $\mathbf{5 6 . 6}$ & $\mathbf{1 . 8}$ \\
\hline $2030 *$ & 324598 & 1293765 & 449320 & 773918 & $\mathbf{5 9 . 8}$ & $\mathbf{1 . 7}$ \\
\hline $2040 *$ & 281881 & 1226022 & 474549 & 756430 & $\mathbf{6 1 . 7}$ & $\mathbf{1 . 6}$ \\
\hline $2050 *$ & 254411 & 1053240 & 562692 & 817103 & $\mathbf{7 7 . 6}$ & $\mathbf{1 . 3}$ \\
\hline
\end{tabular}

Source: Own study based on statistical data of Central Statistical Office.

Age dependency ratio for Poland (65.1 persons for non-working age per 100 of productive one) and the Podkarpackie Voivodeship one, reached levels below the European Union average. Eurostat results indicate that in 2017, in the entire European Union, there were about 3 people of working age per one person in non-productive age.

Data summarized in Table 4 shows that the phenomenon of double aging, signaled in a section above, was not observed in the Podkarpackie Voivodship. It is because, despite a higher increase in the number of people above 85 years of age compared to people aged 65-74, the number of people of "middle" age decreased. The group of people aged 65-74 has been growing the fastest since 2016. Thus, the Podkarpackie Voivodship has a larger

\footnotetext{
${ }^{16}$ The lowest demographic dependency ratio was noted on Opolskie Voivodeship $(61,2)$.
} 
number of people who, with a deficit in the labour market, may be subject to working reactivation, but it will require reform of adequate programs and changes in the labour market policy with a focus on activating seniors.

Table 4. The phenomenon of a double aging society in the Podkarpackie Voivodeship in the years 2012-2018 [persons]

\begin{tabular}{|c|c|c|c|c|c|c|}
\hline age & $65-74$ & $\begin{array}{c}\text { YOY } \\
\text { change (\%) }\end{array}$ & $75-84$ & $\begin{array}{c}\text { YOY } \\
\text { change (\%) }\end{array}$ & $85+$ & $\begin{array}{c}\text { YOY } \\
\text { change (\%) }\end{array}$ \\
\hline 2012 & 93764 & & 66491 & & 18992 & \\
\hline 2013 & 99202 & $\mathbf{5 . 8 \%}$ & 66300 & $\mathbf{- 0 . 3 \%}$ & 20344 & $\mathbf{7 . 1 \%}$ \\
\hline 2014 & 105716 & $\mathbf{6 . 6 \%}$ & 66554 & $\mathbf{0 . 4 \%}$ & 21711 & $\mathbf{6 . 7 \%}$ \\
\hline 2015 & 113297 & $\mathbf{7 . 2 \%}$ & 65796 & $\mathbf{- 1 . 1 \%}$ & 23216 & $\mathbf{6 . 9 \%}$ \\
\hline 2016 & 121444 & $\mathbf{7 . 2 \%}$ & 65136 & $\mathbf{- 1 . 0 \%}$ & 24286 & $\mathbf{4 . 6 \%}$ \\
\hline 2017 & 129813 & $\mathbf{6 . 9 \%}$ & 64203 & $\mathbf{- 1 . 4 \%}$ & 25243 & $\mathbf{3 . 9 \%}$ \\
\hline 2018 & 138810 & $\mathbf{6 . 9 \%}$ & 62889 & $\mathbf{- 2 . 0 \%}$ & 25758 & $\mathbf{2 . 0 \%}$ \\
\hline
\end{tabular}

Source: Own study based on statistical data of Central Statistical Office.

Population ageing process and the acceleration of depopulation in the Podkarpackie Voivodeship are confirmed by statistics on the total fertility rate (Fig. 5).

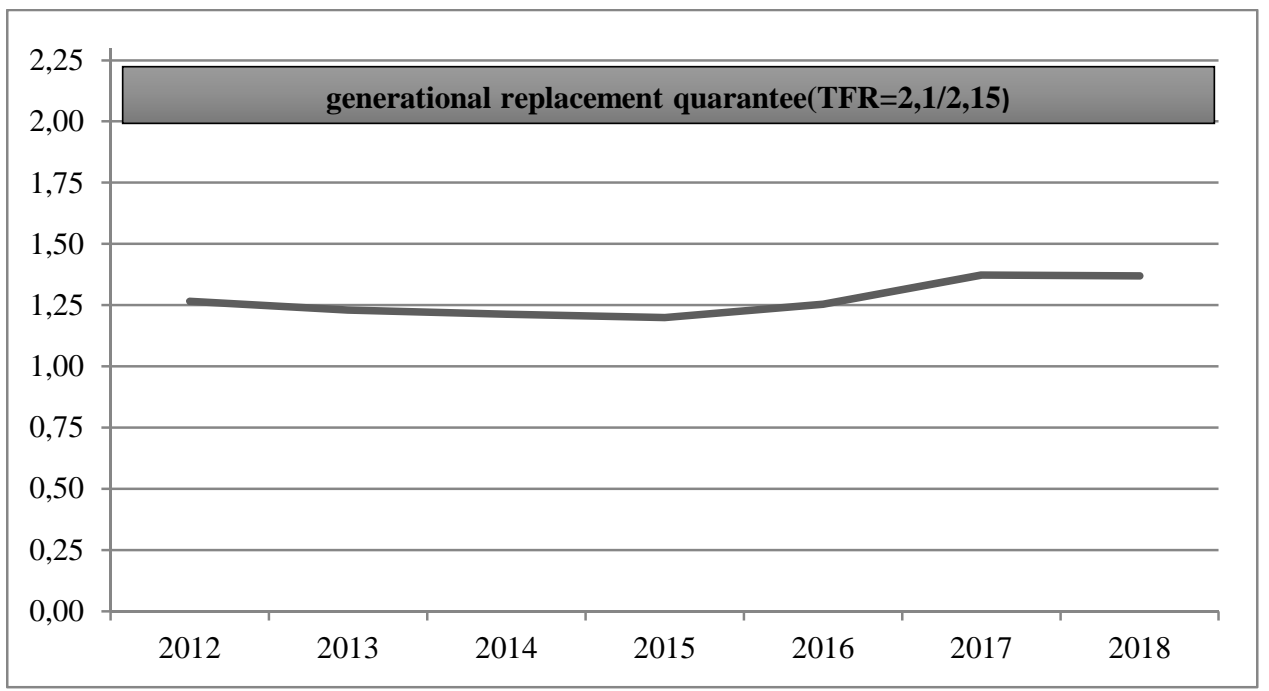

Fig. 5. Total fertility rate in the Podkarpackie Voivodeship in 2012-2018

Source: Own study based on statistical data of Central Statistical Office.

In the years 2012-2015, the TFR decreased, reaching the level of 1.20 in 2015. Thus, four years ago, one woman in her childbearing age (15-49 years old) had an average one child. In 2018, this indicator increased slightly to 1.32 (for Poland the value of the indicator 
in 2018 was 1.44). The "aging" of the regional labour market and a reduction in the number of people of working age can, as a consequence, lead to a significant deficit of "young" employees.

It should be noticed that another significant factor for Podkarpackie labour market, that has an impact for depopulation is migration phenomenon. What is more important, Podkarpackie Voivodeship as yet displayed characteristics for so-called migration region. For an in-depth study of net migration for Podkarpackie Voivodeship the authors separated migration into internal and foreign one (for permanent residence).

The Podkarpackie Voivodeship is characterized by a large scale of emigration of inhabitants to other administrative units of Poland (e.g. study trips, emigration), thus creating a negative net balance of internal migration. In 2018, the difference between internal emigration and immigration in Podkarpackie was approx. 3,000 inhabitants, and this number was $31.4 \%$ higher compared to the previous year.

The reverse situation has been noticed in net foreign migration. Since 2016, due to the increased economic immigration of workers from Ukraine, the balance of permanent and foreign migrations is positive. This situation, if it stays at this level, may be also a remedy for future problems of the Podkarpackie labour market. Economic migrations from Ukraine (as the dominant country in recent years in immigration to Poland as well as in the Podkarpackie Voivodeship) show a yearly substitution character in relation to regional job deficits (Barwińska-Małajowicz, Tęcza, 2018). In 2018, the highest number of offers submitted by employers in poviat labour offices was related to so-called "simple jobs", in which foreigners are most often employed (Occupational Barometer..., 2018).

Despite the positive net external migration, data that shows a net migration divided into working age groups can cause a concern. In the years 2012-2018, a positive migration balance occurred in the case of persons in non-working age (both pre-working and postworking age). The migration balance of people of working age was negative, which means that people who are potentially active and able to work leave the Podkarpackie Voivodeship more often than supply it (Fig. 6).

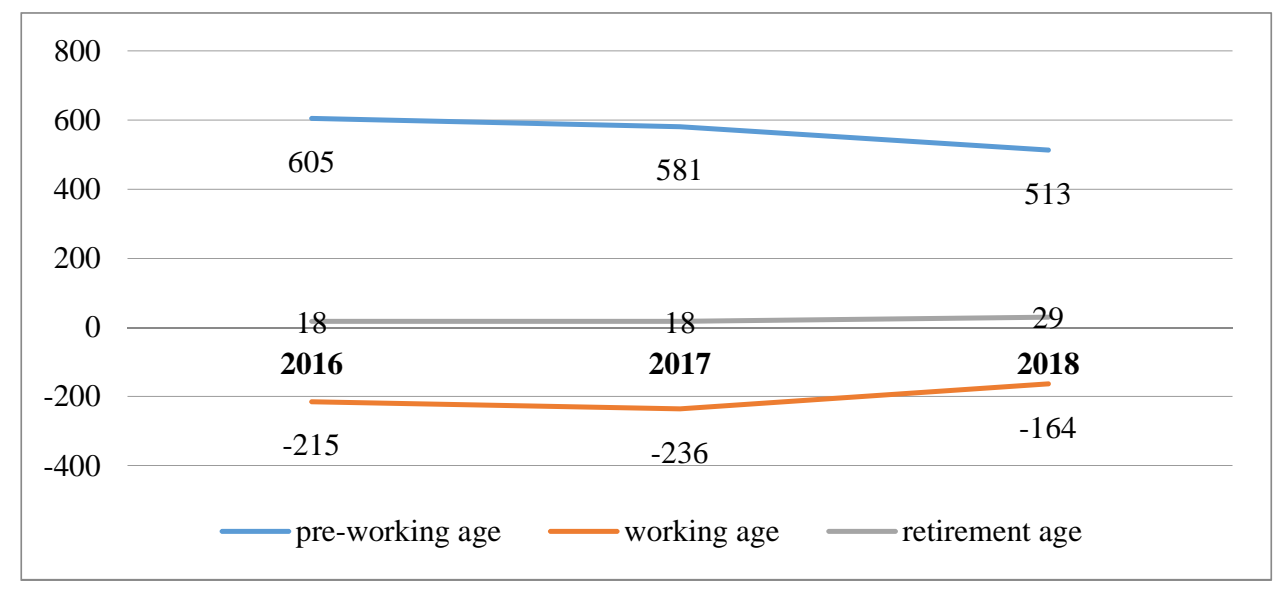

Fig. 6. Balance of international migrations by economic age groups for the Podkarpackie Voivodeship in 2018

Source: Own study based on statistical data of Central Statistical Office. 


\section{SUMMARY}

Despite the difficulties in capturing the economic nature of depopulation, its particular determinants (demographic dependency rate, total fertility rate, net migration) clearly show its destabilizing impact on economic processes. Depopulation affects both macro- and micro-economy structures. In the Podkarpackie Voivodeship, this phenomenon was first recorded in 2013 and from 2018 a long-term forecast shows population decline, which by 2050 will reach the level below 2 million citizens.

In the face of depopulation, the main challenge for the Podkarpackie labour market will be a chronically ageing society, a lack of demand and supply matching of work as well as a negative net, internal migration i.e. the loss of native human capital. Moreover, the demand for professions that already belong to the shortage one (e.g. in a field of medical care) will increase.

Podkarpackie Voivodeship has become more attractive as an investment area (expanding economic zones, attracting foreign capital, creating new workplaces -including in branches of international companies), but lack of labour force may cause a significant slowdown in regional development.

One of the factor that can lead Podkarpackie Voivodeship out of imbalance on the labour market may be foreign immigration (especially from Ukraine), which currently is filling the gaps in deficit professions in the region.

The depopulation process in Podkarpackie Voivodeship is inevitable, which is why effective striving for balancing the regional labour market should also depend on the proper implementation of market strategies developed on the basis of thorough research of current and future population structure of Podkarpackie Voivodeship.

\section{REFERENCES}

Adamczyk, D.M. (2017). Starzenie się społeczeństwa polskiego wyzwaniem dla zrównoważonego rozwoju. „Zeszyty Naukowe. Organizacja i Zarzadzanie”. Politechnika Śląska.

Barwińska-Małajowicz, A., Tęcza, K. (2018). Imigracja pracowników z Ukrainy do Polski dynamika $i$ charakter zmian na podkarpackim rynku pracy. „Zeszyty Naukowe WSES w Ostrotęce” 1/2018(28).

Beck, U. (2004). Społeczeństwo ryzyka. W drodze ku innej nowoczesności. Warszawa: Scholar. Brzychcy, K. (2011). Rynek pracy jako obszar wzajemnych relacji - próba identyfikacji problemu. „Zeszyty Naukowe Uniwersytetu Szczecińskiego Ekonomiczne problemy ustug” nr 77.

Drzeżdżon, W. (2011). Przeobrażenia polskiego rynku pracy u progu XXI wieku. Wyzwania dla pedagogiki pracy [w:] Studia Gdańskie. Wizje i rzeczywistość, t. VIII, Gdańska Wyższa Szkoła Humanistyczna, Gdańsk.

Dybowska, J., Widera, K. (2015). Demograficzne uwarunkowania i skutki depopulacji w województwie opolskim [w:] Harasim, J., red., Studia Ekonomiczne. Zeszyty Naukowe Uniwersytetu Ekonomicznego w Katowicach $\mathrm{nr}$ 233/15.

Dylkiewicz, B.R. (2013). Czynniki ekonomiczne determinujące rynek pracy województwa zachodniopomorskiego. „Nierówności Społeczne a Wzrost Gospodarczy”. Rzeszów: UR.

Golinowska, S. (2011). Teorie migracji a debata o swobodzie przeptywu pracowników w rozszerzonej Unii Europejskiej [w:] Problemy polityki społecznej. Studia i dyskusje, t. 3. Warszawa: Polska Akademia Nauk Komitet Nauk o Pracy i Polityce Społecznej. 
Grzywna, P. (2014). Demograficzne aspekty bezpieczeństwa społecznego Polski na początku XXI wieku [w:] Czornik, K., Lakomy, M., red. nauk., Dylematy polityki bezpieczeństwa Polski na początku drugiej dekady XXI wieku. Katowice: Regionalny Ośrodek Debaty Międzynarodowej w Katowicach.

Guzikowski, M. (2016). Wptyw zmian demograficznych na regionalne rynku pracy w Polsce. „Studia Ekonomiczne. Zeszyty Naukowe Uniwersytetu Ekonomicznego w Katowicach” nr 276.

Jędruszczak, H. (1964). Rynek pracy w Polsce międzywojennej [w:] Najnowsze dzieje Polski, 1914-1939, t. VII. Warszawa.

Jóźwiak, J. (2013). Demograficzne uwarunkowania rynku pracy w Polsce [w:] Kiełkowska, M. Jankowska, M., red., Rynek pracy wobec zmian demograficznych. Zeszyty Demograficzne Instytutu Obywatelskiego, Warszawa.

Koprowicz, A. (2017). Sytuacja demograficzna Podkarpacia - stan obecny i perspektywy [w:] Hrynkiewicz, J., Potrykowska, A., red. nauk., Sytuacja demograficzna Podkarpacia jako wyzwanie dla polityki społecznej i gospodarczej. Warszawa: Rządowa Rada Ludnościowa.

Kotowska, E.I., red. (2014), Niska dzietność w Polsce w kontekście percepcji Polaków. Diagnoza Społeczna - raport tematyczny. Warszawa: Ministerstwo Pracy i Polityki Społecznej: Centrum Rozwoju Zasobów Ludzkich.

Kotowska, E.I., Jóźwiak, J. (2012). Nowa demografia Europy a rodzina [w:] Plebaniak, J., red., Roczniki Kolegium Analiz Ekonomicznych/Szkoła Główna Handlowa. Zeszyt 28/2012, Warszawa.

Program Rozwoju Edukacji w Województwie Podkarpackim do roku 2020, Rzeszów 2017 r., https://www.ko.rzeszow.pl [access: 12.12.2019].

Trąbka, A. (2018)., Zmiany przywiązania do miejsca zamieszkania pod wptywem mobilności $i$ ich znaczenie dla dobrostanu jednostki [w:] Anczyk, A., Grzymała-Moszczyńska, J., Krzysztof-Świderska, A., red., Psychologia kultury - kultura psychologii. Katowice: Wydawnictwo Sacrum.

WUP Rzeszów, Barometr zawodów 2019 - Raport podsumowujący badanie w województwie podkarpackim, Kraków 2018, https://barometrzawodow.pl [access: 13.12.2019].

DOI: $10.7862 /$ rz.2020.hss.25

The text was submitted to the editorial office: December 2019.

The text was accepted for publication: September 2020. 